\title{
EXCESS BODY WEIGHT AS A RISK FACTOR TO WELL-BEING AND PERFORMANCE OF FLIGHT PERSONNEL: POTENTIAL STRATEGIES OF PREVENTION
}

\author{
Agata GAŹDZIŃSKA ${ }^{1}$ Rafał WÓJCIK¹, Michał JANEWICZ , Marek BINDER², MariusZ \\ WYLEŻOŁ' ${ }^{1}$, Stefan P. GAŹDZIŃSKI ${ }^{1}$ \\ ${ }^{1}$ Military Institute of Aviation Medicine, Warsaw, Poland \\ 2 Department of Psychology, Jagiellonian University, Krakow, Poland
}

Source of support: Polish National Science Centre (NCN): 2013/09/B/NZ7/03763 (to SPG)

Author's address: S.P. Gaździński, Military Institute of Aviation Medicine, Krasińskiego 54/56 Street, 01-755 Warszawa, Poland, e-mail:sgazdzin@wiml.waw.pl

Abstract: Flight personnel is at risk of excessive weight and obesity. This is due to, for instance, irregular work schedules, irregular nutritional habits, excessive workload, and an inability to plan regular physical exercise or recreation. These factors lead to excessive body weight gains, and hence to obesity. Obesity directly influences quality of life as well as readiness to fulfill duties by the aircraft maintenance personnel. Obesity is an independent risk factor for various diseases such as hypertension, type 2 diabetes, coronary artery disease, atherosclerosis, each of which can lead to a loss of medical licence.

Obesity is associated with extensive caloric consumption that cannot be controlled by the affected person. State of the art research has demonstrated not only hormonal and neuronal changes associated with obesity, but also points to deterioration of cognitive functions; these changes are likely induced by suboptimal diets. Furthermore, we will review prevention strategies, as well as treatments aimed at losing weight in flight personnel already affected by obesity. Implementation of these programs may prolong the time a pilot is fit to fly and improve his/her performance.

Keywords: dietary interventions, flight personnel, lifestyle, neuroimaging, obesity

Figures: 2 • References: 77 • Full-text PDF: http://www.pjamp.com • Copyright @ 2014 Polish Aviation Medicine Society, ul. Krasińskiego 54/56, 01-755 Warsaw, license WIML •Indexation: Index Copernicus, Polish Ministry of Science and Higher Education 


\section{INTRODUCTION}

Not only is obesity an independent risk factor for various diseases such as hypertension, type 2 diabetes, coronary artery disease, atherosclerosis, but it also directly influences quality of life as well as readiness to perform duties by flight personnel. Physicians who specialize in aviation medicine estimate that in the Polish population approximately $50 \%$ of flight personnel is either overweight or obese. Research carried out among the military personnel of different countries points to an increasing body mass index (BMI) among soldiers $[1,53]$. Excessive body weight and obesity is found in young recruits as well as in experienced soldiers $[27,32]$.

Consistent with it, our studies with participation of students of Polish Air Force Academy demonstrated elevated body weight accompanied by elevated fat fraction [30,31]. The problem of obesity is aggravated by irregular work schedules, irregular eating habits, excessive workload caused by an inadequate number of personnel, and inability to plan regular physical exercise or recreation [9].

Weight gain problem in aviation parallel the increase in adiposity in the general population of Poland [75,76], and worldwide. Worldwide prevalence of obesity has reached epidemic proportions. In 2014, more than 1.9 billion adults, 18 years and older, were overweight, i.e., their BMI was larger than 25 . Of these over 600 million were obese (BMI > 30). Once considered a problem only in high-income countries, obesity are now dramatically on the rise in low- and middle-income countries (WHO fact sheet No 311, updated January 2015).

\section{Neuronal changes associated with obesity}

Obesity is associated with conditions such as insulin resistance or type 2 diabetes, hypertension, and dyslipidemia. When at least two of these symptoms appear together with (abdominal) obesity, the condition is termed metabolic syndrome (MetS) [4]. Obesity, old age, and physical inactivity are the major drivers of MetS development, which affects $20-30 \%$ of adult population in most countries [20] and 25\% population in Poland [77]. MetS is a cluster of risk factors for cardiovascular disease. It consists of dyslipidemia, elevation of blood pressure and glucose, as well as prothrombic and proinflammatory states. Many persons with metabolic syndrome have insulin resistance, which predisposes them to prediabetes or type 2 diabetes [20]. Obesity is a leading preventable cause of death in the United States [38]. Even in India, the number of deaths due to obesity surpassed the number of deaths associated with malnutrition [44]. Obesity and metabolic syndrome are associated with higher medical costs and loss of productivity. In the United States alone, the economic cost of treating conditions related to obesity was estimated at $\$ 190$ billion a year (http://www.hsph. harvard.edu/obesity-prevention-source/obesityconsequences/economic/) and is expected to rise [67]. Regrettably, nowadays Europe also faces severe problem of obesity and MetS, and European societies bear ascending medical costs related to these conditions (e.g., [52]. We are not aware of any studies assessing the costs of obesity among flight personnel.

Recent studies highlighted the brain as a new target of detrimental effects of obesity and metabolic syndrome. Epidemiological studies consistently find that midlife obesity is a risk factor for Alzheimer's disease (reviewed in [3], especially abdominal obesity [71] that is associated with insulin resistance and metabolic syndrome [8]). Finally, midlife obesity is a risk factor for developing dementia decades later in life, independently of comorbid conditions [70], especially if accompanied by abdominal/visceral obesity [71]. Obesity was also linked to accelerated aging in women [59].

They likely reflect some abnormality/changes of the central nervous system related to obesity and metabolic syndrome. In fact, in-vivo magnetic resonance imaging studies found smaller brain volumes of healthy elderly related to elevated BMI (e.g., [48,68]), with the former study reporting atrophy mostly in frontal lobe and anterior cingulated cortex (ACC), brain structures supporting higher cognitive functions. Additionally, elevated BMI among healthy young obese was associated with some changes in brain morphology $[25,43]$. Interestingly, Gunstad et al [23] reported smaller gray matter volumes in middle-aged, healthy individuals with elevated BMI. Other studies reported associations between morphological changes in the brain and elements of metabolic syndrome. These associations are of significance, as smaller brain volume (more brain atrophy) is a risk factor for cognitive decline in individuals approaching old age.

Obesity and metabolic syndrome are not only related to structural brain changes, but also to its function. Lower glucose metabolism in ACC and prefrontal cortex, as well as functional dysregulation of these structures were recently found in obese individuals [66] and were related to lower striatal dopamine D2 receptor availability $[60,63]$. In an independent groups of overweight and mor- 
bidly obese individuals, but not in individuals at healthy weight (control group), striatal dopamine D2 receptor availability was inversely related to $\mathrm{BMI}$, suggesting that dopaminergic system is involved in compulsive eating [24,64]. Similar abnormalities in dopamine D2 receptors, as described above, were induced in rodents just over 40 days on a Cafeteria diet (high fat, high carbohydrates) [28]. Other studies reported deficits of mesolimbic dopamine transmission in rodents fed high-fat diet (e.g.,[19]), consistent with findings in obese humans [61]. The mechanisms behind these associations are not completely understood and are not subject of this review.

Neuroimaging studies reported morphological changes in the brains of obese individuals $[24,43]$, whereas magnetic resonance spectroscopic studies showed lower concentrations of $\mathrm{N}$-acetyloaspartate (NAA) that is a marker of neuronal integrity $[15,16]$ suggesting slowed down neuronal metabolism. The latter result is consistent with lower glucose metabolism [62] and lower cerebral blood flow (perfusion) [72] reported in same brain region. Magnetic resonance spectroscopic study of diabetic patients demonstrated similar pattern of lower NAA concentrations and increased myoinostitol concentrations throughout the brain, suggesting inflammatory state [51]. Additionally, resting-state functional magnetic resonance studies demonstrated abnormalities in functional connectivity in the brains of obese persons $[33,57]$.

\section{Cognitive changes associated with obesity}

Obesity and MetS are also associated with generally poorer cognitive skills in affected individuals. Both elevated BMI and MetS have been associated with poorer learning and memory in the elderly and poorer executive functions (problem solving, decision making) throughout lifetime (e.g., $[21,40,73])$, whereas metabolic syndrome has been additionally related to poorer learning and recall impairment in middle age [26]. There is growing evidence for an association between obesity and poorer executive function reflecting higher order thinking, reasoning, judgment, and planning, both in adults $[22,36,45,65]$ and even in obese children [7]. There were also reports of poorer memory and poorer visuospatial abilities among obese individual compared to individuals at healthy weight $[12,21,56]$. The impact of these deficits on flight performance was not evaluated.

On the other hand, higher BMI has been associated with better attention and visuospatial ability [21], possibly reflecting adaptation to office work. Nevertheless, elevated BMI and BMI increases with age were associated with faster cognitive decline $[21,50]$. This is relevant also to aviation, as obesity may shorten the time when a pilot is fit to fly, independently of co-morbid medical conditions.

\section{The role of diet}

Long-term consumption of high-fat diets promotes insulin resistance and obesity both in rodents and humans $[2,58]$. Animal studies point to cause-effect relationship between obesity and cognitive functions. Poorer learning and memory were reported in animals fed high-fat diets (e.g.,[69]) and diets with high sucrose content [29]. Moreover, excessive weight and triglyceridemia resulted in poorer acquisition of new information in mice [13]. Rats on high-fed diet, compared to a control group, demonstrated decline in retention, but not acquisition, in the water maze [69], showing some resemblance of learning and memory abnormalities reported in humans with metabolic syndrome [26]. Taken together, these results demonstrate detrimental effects of obesity and metabolic syndrome on cognitive functions.

\section{Brain reactions to food related cues}

The cause of obesity is positive energy balance with energy intake exceeding its expenditure. Obesity, weight gain are not due to inability to stick to one's decision. State of the art research points to hormonal, neurohormonal, and neural [5]. Recent studies have also pointed to gastrointerstinal hormone imbalance (reviewed in [49]) and abnormal neuronal responses to appetitive stimuli (reviewed in [5]). The latter studies, using functional imaging techniques including functional magnetic resonance imaging (fMRI), demonstrated heightened responses to visual food cues with cognitive effort to restrain consumption $[5,33]$. This is illustrated in Fig. 1. with our own data obtained at Creative NeuroScience (CNS) Lab at our institution hosting a 3T GE Discovery MRI scanner.

Visual food cues, i.e., pictures of palatable food induce increases activations in nucleus accumbens, ventral striatum, anterior insula, amygdala, and orbitofrontal cortex interpreted as reflecting emotional processing, emotional decision making, and taste (reviewed in [5]). On the other hand, the increased activations in caudate and putamen (dorsal striatum), medial-, lateral- and orbito-frontal cortex, as well as anterior cingulate cortex are interpreted as activation of motivation and cognitive inhibition likely aimed at resist consuming the palatable food. This is confirmed by our preliminary comparisons of brain reactions to high-caloric vs. low caloric foods that show differences 

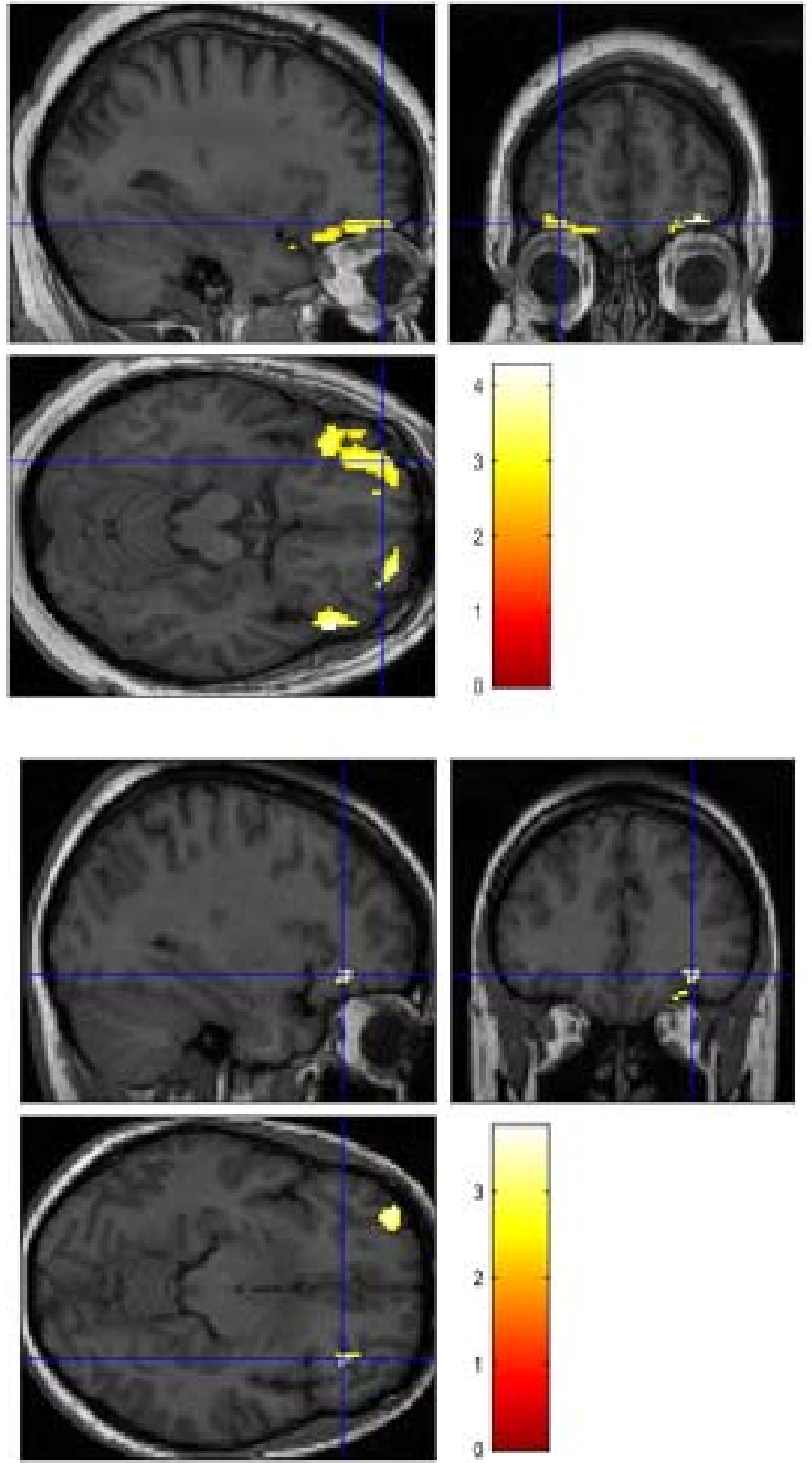

Fig. 1. Visually larger extent of activations of orbitofrontal cortex in obese patient (above) than in a volunteer at healthy weight in response to high- vs. low-calorie foods ( $p=0.005$, uncorrected). Orbitofrontal cortex is believed to be involved in emotional processing and emotional decision making.

between a morbidly obese individual $(\mathrm{BMI}=60)$ and a volunteer at healthy weight (BMI = 21; Fig. 2.).

However, among morbidly obese individuals, lower activations in dorsolateral prefrontal cortex and anterior cingulated cortex (ACC), as well as in orbitofrontal cortex and somatosensory cortex in the obese participants than in lean patients were observed [63], suggesting less cognitive effort to restrain consumption (see Fig. 1.). These abnormalities were related to lower striatal dopamine D2 receptor availability, as revealed in positron emission tomography (PET) studies (reviewed in [60]). However, the 

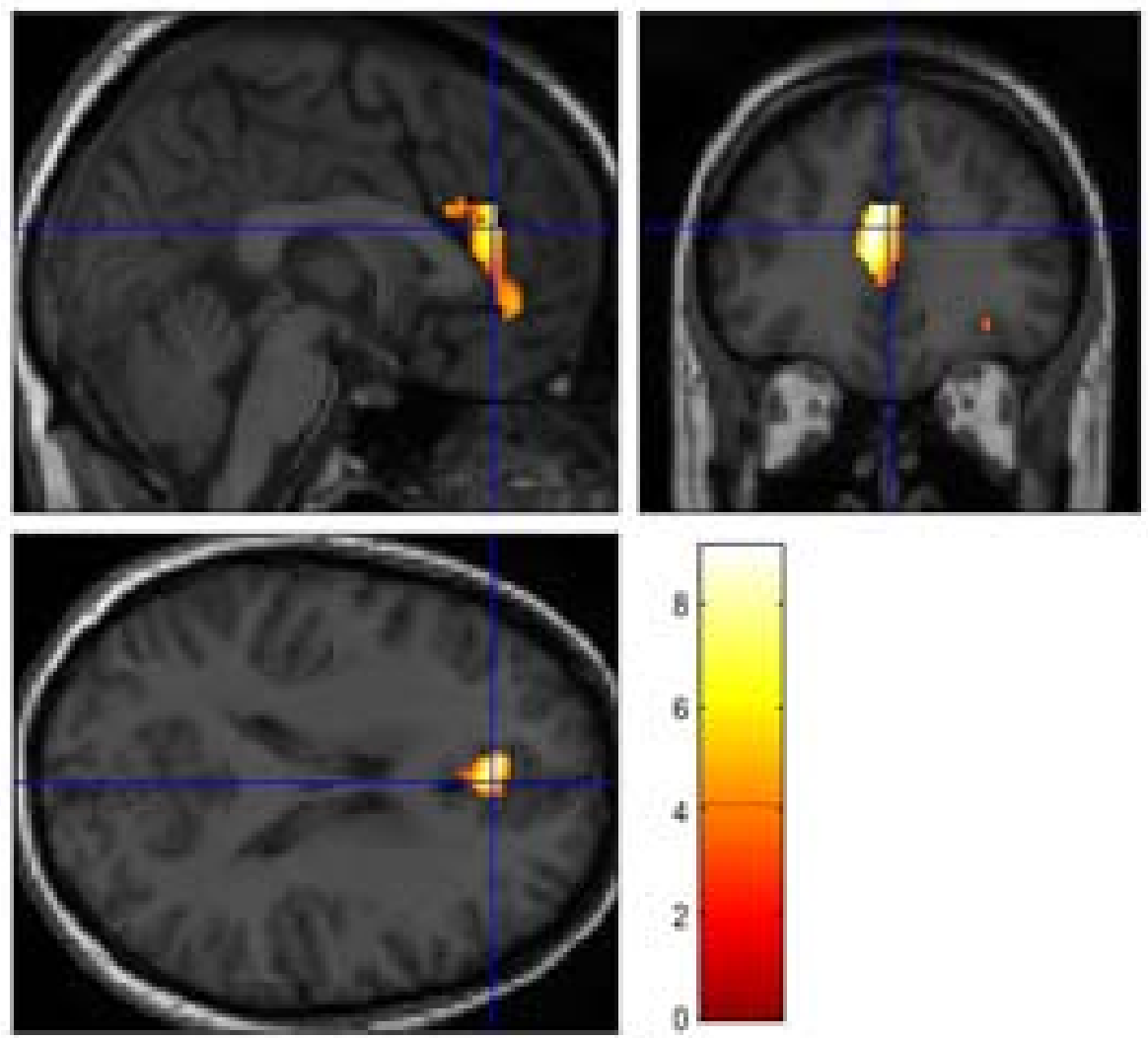

Fig. 2. Activation of Anterior Cingulate Cortex (ACC) in response to high-calorie vs. low-calorie foods in a healthy weight volunteer associated with decision making. This activation was not present in an obese patient.

level of exercise is known to affect behavioral appetitive control [37]. Furthermore, the level of activations in response to visual cues of palatable food may predict future consumption [34] and future weight gain.

\section{Potential strategies to identify pilots at risk of obesity}

Aforementioned changes in neural reactions to appetitive foods likely precede weight gain and onset of obesity. The same likely applies to hormonal changes that are known to accompany obesity. It is likely these changes are related to brain alterations accompanying bariatric surgeries - the only known method for lasting weight loss. E.g., gastric bypass surgery resulted postoperative reductions in mesolimbic (e.g., stiatal) neural responsivity, lower desire to eat of highrelative to low caloric food within three months of the surgery, despite weight loss of less than $5 \%$ of body weight, suggesting that these neural responsivity changes in fact precede weight loss. Reductions in food wanting due to the surgery were also related to reductions in inhibitory activations in dorsolateral prefrontal cortex $[41,42]$. Currently, at the Military Institute of Aviation
Medicine a project evaluating changes in cognition and neuronal correlates of appetite due to insertion of intragastric balloon is underway.

It is possible that individuals currently at healthy weight, but at risk of excessive fat accumulation and obesity have hormonal and brain responses to food similar to obese individuals. Identification of such individuals would allow for early interventions, shortened treatments, and cost savings.

\section{Strategies to prevent weight gain and obesity}

Prevention of obesity-related complications costs less than their treatment, as is the case in other fields of medicine. These economic considerations have an additional aspect in the case of flight personnel. When obesity-related complications lead to revocation of medical licence of an experienced pilot, years of training are needed to replace him/her.

In accordance with contemporary medical knowledge, to prevent development of conditions co-morbid with obesity, a complex system of care has to be introduced. The aim of this system is early diagnosis of impeding weight problems through detection of excessive body weight with 
an accumulation of adipose tissue. That enables a therapeutic intervention. Obesity experts agree that it is necessary to manage obese patients in a comprehensive manner. Currently, a holistic approach toward obesity includes:

- Alternation of nutritional habits with the use of modern nutritional medicine methods;

- Physician-guided pharmacological support of losing weight;

- Psychological support in individual or group therapy;

- Gradually increasing daily physical exercise that is suited to the state of health and capabilities of the patient;

- Possible surgical treatment.

Such a comprehensive approach is substantiated by studies reporting favorable outcomes of the management of obesity $[14,39,54]$. The main principles of obesity management are based on a long-term program, often lasting throughout a life span, as obesity is a chronic disease not remitting spontaneously. Management of obesity should take into account risk factors for obesity and be concentrated on the maintenance of normal body weight in the long term.

Appropriate method should be selected for each patient individually. With the development of nutritional medicine it has become clear that rational nutrition is the single most important factor that reduces the risk of obesity and other nutrition-dependent diseases. Typically, management of the majority of diseases necessitates the introduction of a nutritional program that potentiates pharmacotherapy, decreases hospitalization time, and reduces the risk of complications. Therefore, dieticians and a well-organized nutritional counseling system play a fundamental role in the fight with the epidemic of obesity. Nutritional counseling is a very important element of global as well as European strategies aimed at prevention of excessive weight and/or obesity, and co-morbid chronic non-communicable diseases (for instance, hypertension, allergies, ischemic heart disease). It constitutes an integral part of the entire approach towards obesity. A well-balanced diet tailored to metabolic needs and nutritional deficiencies increases the effectiveness of pharmacotherapy and surgical treatments and reduces the prevalence of complications (for instance, urinary tract infection, respiratory infections), number of deaths, duration of treatment and rehabilitation, and health-care spending.

Currently, a dietitian is an interdisciplinary specialist who analyzes food products, plans, employs and oversees evidence-based nutritional pro- grams for individuals and groups. Dietician-guided nutritional education is especially important in order to form correct attitudes towards nutrition with a special focus on appropriate food selection, meal planning, and use of adequate food preparation technologies [17].

Educational activities that are suited to socioeconomic needs and conditions of patients should contribute to formation of health-oriented attitudes. Basic tasks of nutritional counseling in terms of prevention and management of obesity are the correction of inappropriate nutritional behaviors and more importantly the encouragement to change lifestyle and to increase physical activity.

Regular physical exercise that increases energy expenditure leads not only to a reduction of excessive body weight but causes also many favorable changes in the organisms such as an increase in muscle mass, gain in bone mass, improvement in glucose and lipid metabolism, reduction in resting arterial blood pressure, and improvement of wellbeing and general mental functioning $[46,74]$.

Physical activity that is recommended for health promotion and prophylaxis of cardiovascular diseases includes the following: physical exercise three times a week, moderate intensity of exercise (approximately $60 \%$ of maximal pulse, duration of 20-60 minutes), endurance exercise, and adjunctive resistance training. Energy expenditure during one session of exercise should amount to 200$300 \mathrm{kcal}$ and $1000 \mathrm{kcal}$ for a whole week [10].

According to the literature on management of prevention of excessive body weight and obesity, 45-60 minutes of daily exercise is recommended for preventions of excessive body weight whereas 60-90 minutes of daily exercise should be performed in order to prevent relapses of obesity. Daily exercise should be planned in 30-minute blocks which can be gradually increased $[47,55]$. The frequency of training in people with excessive body weight and obesity should not be lower than two sessions a week, but a frequency of 3-6 sessions a week of dynamic exercise lasting 30-60 minutes is preferred $[18,47]$.

People with excessive body weight and obesity have a low physical exercise capacity and agility and therefore the frequency of training should be suited to their capabilities in order to minimize the risk of cardiovascular complications, and musculoskeletal injury. Moderate exercise intensity is recommended (30-70\% of maximal intensity) without an excessive strain of knee joints, hip joints, and vertebral joints [17]. 
It has been shown many times that accelerometers are an efficient tool for the assessment of the actual level of physical exercise. Additionally, they play an educational and motivational role with respect to healthy lifestyle promotion, and increasing the amount of time spent actively $[11,35]$.

Management of obesity is a long-term process with no single universal treatment approach [6]. Prevention and management of excessive body weight and obesity among military personnel should be based on a systematic assessment of nutritional state - evaluation of body composition, anthropometric analysis enabling early diagnosis at periodic health examinations [6], detailed procedures of dealing with obese patients depending on BMI values, and body composition values, assessment of nutritional knowledge regarding physical exercise, and health-oriented behaviors among flight personnel. Promotion and introduction of appropriate nutrition and other health-oriented activities including popularization of physical exercise among military personnel through establishing an internet platform for health promotion, which should also be available as a mobile application. Access to a "virtual dietician" would make the employment of nutritional recommendations easier regardless of location.

\section{CONCLUSIONS}

Obesity is a serious risk to flying personnel that can adversely affect their performance and puts them at risk of medical conditions that could shorten their carriers, such as heart disease or cancers, to name a couple. Preventive strategies to reduce stress and improve quality of life should be employed. Nevertheless, tools identifying flight personnel at the highest risk of developing obesity would be of interest.

\section{AUTHORS' DECLARATION:}

Study Design: Agata Gaździńska, Rafał Wójcik, Michał Janewicz, Marek Binder, Mariusz Wyleżoł, Stefan P. Gaździński; Data Collection: Agata Gaździńska, Rafał Wójcik, Michał Janewicz, Marek Binder, Mariusz Wyleżoł, Stefan P. Gaździński; Manuscript Preparation: Agata Gaździńska, Rafał Wójcik, Michał Janewicz, Marek Binder, Mariusz Wyleżoł, Stefan P. Gaździński; Funds Collection: Agata Gaździńska, Rafał Wójcik, Michał Janewicz, Marek Binder, Mariusz Wyleżoł, Stefan P. Gaździński. The Authors declare that there is no conflict of interest.

\section{REFERENCES}

1. Bae KK, Kim H, Cho SI. Trends in body mass index and associations with physical activity among career soldiers in South Korea. J Prev Med Public Health 2011; 44(4):167-75.

2. Banas SM, Rouch C, Kassis N, Markaki EM, Gerozissis K. A Dietary Fat Excess Alters Metabolic and Neuroendocrine Responses Before the Onset of Metabolic Diseases. Cellular and Molecular Neurobiology 2009; 29(2):157-68.

3. Beydoun MA, Beydoun HA, Wang Y. Obesity and central obesity as risk factors for incident dementia and its subtypes: a systematic review and meta-analysis. Obes Rev 2008; 9(3):204-18.

4. Buettner R, Scholmerich J, Bollheimer LC. High-fat diets: Modeling the metabolic disorders of human obesity in rodents. Obesity 2007; 15(4):798-808.

5. Carnell S GC, Benson L, Ochner CN, Geliebter A. Neuroimaging and obesity: current knowledge and future directions. Obesity Reviews 2012; 13(1):43-56.

6. Ciota M, Cisłak P, Błaszczyk R, Fornal R, Dworzański T. Profilaktyka i leczenie otyłości. . Annales Uniwersitatis Mariae CurieSkłodowska 2005; 60(16):256-60.

7. Cserjesi R, Molnar D, Luminet $\mathrm{O}$, Lenard L. Is there any relationship between obesity and mental flexibility in children? Appetite 2007; 49(3):675-8.

8. Despres JP, Lemieux I. Abdominal obesity and metabolic syndrome. Nature 2006; 444(7121):881-7.

9. Dębska A, Kłossowski M. Analiza wpływu różnych czynników na zjawisko nadwagi i otyłości u personelu latającego. Polski Przegląd Medycyny Lotniczej 2006; 2(12):125-36.

10. Drygas W, Kostka T, Jegier A, Kunski H. Long-term effects of different physical activity levels on coronary heart disease risk factors in middle-aged men. International Journal of Sports Medicine 2000; 21(4):235-41. 
11. Dwyer T, Hosmer D, Hosmer T, Venn AJ, Blizzard CL, Granger RH, et al. The inverse relationship between number of steps per day and obesity in a population-based sample - the AusDiab study. International Journal of Obesity 2007; 31(5):797-804.

12. Elias MF, Elias PK, Sullivan LM, Wolf PA, D’Agostino RB. Lower cognitive function in the presence of obesity and hypertension: the Framingham heart study. Int J Obes Relat Metab Disord 2003; 27(2):260-8.

13. Farr SA, Yamada KA, Butterfield DA, Abdul HM, Xu L, Miller NE, et al. Obesity and hypertriglyceridemia produce cognitive impairment. Endocrinology 2008; 149(5):2628-36.

14. Felinczak A, Sen M, Kaminski W, Waszczak J, Sikora A, Fal A, et al. Aktywność fizyczna a redukcja masy ciała : opis programu zdrowotnego. Medicina Sportiva Practica 2008; 2:27-30.

15. Gazdzinski S, Kornak J, Weiner MW, Meyerhoff DJ. Body mass index and magnetic resonance markers of brain integrity in adults. Annals of Neurology 2008; 63(5):652-7.

16. Gazdzinski S, Millin R, Kaiser LG, Durazzo TC, Mueller SG, Weiner MW, et al. BMI and Neuronal Integrity in Healthy, Cognitively Normal Elderly: A Proton Magnetic Resonance Spectroscopy Study. Obesity 2010; 18(4):743-8.

17. Gaździńska A. Rola dietetyka w sprawowaniu opieki nad chorymi leczonymi operacyjnie z powodu otyłości. Medycyna praktyczna - Chirurgia 2012; 101(1):38-41.

18. Gaździńska A, Truszczyński OE, Wyleżoł M, Różanowski K, Kłossowski M. Aktywność fizyczna jako jeden z elementów zapobiegania i leczenia nadwagi i otyłości u wojskowego personelu latającego. Polski Przegląd Medycyny Lotniczej 2010; 1:15-26.

19. Geiger BM, Haburcak M, Avena NM, Moyer MC, Hoebel BG, Pothos EN. Deficits of mesolimbic dopamine neurotransmission in rat dietary obesity. Neuroscience 2009; 159(4):1193-9.

20. Grundy SM. Metabolic syndrome pandemic. Arteriosclerosis Thrombosis and Vascular Biology 2008; 28(4):629-36.

21. Gunstad J, Lhotsky A, Wendell CR, Ferrucci L, Zonderman AB. Longitudinal Examination of Obesity and Cognitive Function: Results from the Baltimore Longitudinal Study of Aging. Neuroepidemiology 2010; 34(4):222-9.

22. Gunstad J, Paul RH, Cohen RA, Tate DF, Spitznagel MB, Gordon E. Elevated body mass index is associated with executive dysfunction in otherwise healthy adults. Compr Psychiatry 2007; 48(1):57-61.

23. Gunstad J, Paul RH, Cohen RA, Tate DF, Spitznagel MB, Grieve S. Relationship between body mass index and brain volume in healthy adults. International Journal of Neuroscience 2008; 118(11):1582-93.

24. Haltia LT, Rinne JO, Merisaari H, Maguire RP, Savontaus E, Helin S, et al. Effects of intravenous glucose on dopaminergic function in the human brain in vivo. Synapse 2007; 61(9):748-56.

25. Haltia LT, Viljanen A, Parkkola R, Kemppainen N, Rinne JO, Nuutila P, et al. Brain white matter expansion in human obesity and the recovering effect of dieting. J Clin Endocrinol Metab 2007; 92(8):3278-84.

26. Hassenstab JJ, Sweat V, Bruehl H, Convit A. Metabolic Syndrome Is Associated with Learning and Recall Impairment in Middle Age. Dementia and Geriatric Cognitive Disorders 2010; 29(4):356-62.

27. Hsu LL, Nevin RL, Tobler SK, Rubertone MV. Trends in overweight and obesity among 18-year-old applicants to the united states military, 1993-2006. Journal of Adolescent Health 2007; 41(6):610-2.

28. Johnson PM, Kenny PJ. Dopamine D2 receptors in addiction-like reward dysfunction and compulsive eating in obese rats (vol 13, pg 635, 2010). Nature Neuroscience 2010; 13(8):1033-.

29. Jurdak N, Kanarek RB. Sucrose-induced obesity impairs novel object recognition learning in young rats. Physiology \& Behavior 2009; 96(1):1-5.

30. Kłos A, Bertrandt J, Gaździńska A. Anthropometric assessment of nutritional status of female and male candidates for the Polish Air Force Academy. Lekarz Wojskowy 2007; 83(2):119-21.

31. Kłosowski M, Dębska A, Stelęgowski A. Ocena problemu nadwagi u podchorążych i pilotów wojskowych w wieku 18-45 lat. Nowiny Lekarskie 2008; 3:31-42.

32. Kobos Z, Bednarski W, Bertrandt J, Kłos A, Bieniek R. Psychologiczne uwarunkowania otyłości wśród personelu lotnictwa. Żywienie Człowieka i Metabolizm 2003; 30:237-9.

33. Kullmann S HM, Veit R, Ketterer C, Schick F, Häring HU, Fritsche A, PreissI H. The obese brain: association of body mass index and insulin sensitivity with resting state network functional connectivity. Human Brain Mapping 2012; 33(5):1052-61.

34. Lawrence NS HE, Parkinson JA, Lawrence AD. Nucleus accumbens response to food cues predicts subsequent snack consumption in women and increased body mass index in those with reduced self-control. Neuroimage 2012; 61(1):415-22.

35. Liu S, Gao RX, Freedson PS. Computational Methods for Estimating Energy Expenditure in Human Physical Activities. Medicine and Science in Sports and Exercise 2012; 44(11):2138-46.

36. Lokken KL, Boeka AG, Austin HM, Gunstad J, Harmon CM. Evidence of executive dysfunction in extremely obese adolescents: a pilot study. Surg Obes Relat Dis 2009; 5(5):547-52. 
37. Martins C ML, Truby H. A review of the effects of exercise on appetite regulation: an obesity perspective. International Journal of Obesity 2008; 32(9):1337-47.

38. Mokdad AH, Marks JS, Stroup DF, Gerberding JL. Actual causes of death in the United States, 2000. Jama-Journal of the American Medical Association 2004; 291(10):1238-45.

39. Niewada M, Członkowski A, Rewerski W. Ile kosztuje otyłość? Medycyna po Dyplomie 2000; 4:12-7.

40. Noble JM, Manly JJ, Schupf N, Tang MX, Mayeux R, Luchsinger JA. Association of C-Reactive Protein With Cognitive Impairment. Archives of Neurology 2010; 67(1):87-92.

41. Ochner CN KY, Conceição E, Pantazatos SP, Puma LM, Carnell S, Teixeira J, Hirsch J, Geliebter A. Selective reduction in neural responses to high calorie foods following gastric bypass surgery. Annals of Surgery 2011; 253(3):502-7.

42. Ochner CN SE, Hutchins E, Afifi L, Geliebter A, Hirsch J, Teixeira J. Relation between changes in neural responsivity and reductions in desire to eat high-calorie foods following gastric bypass surgery. Neuroscience 2012; 209:128-35.

43. Pannacciulli N, Del Parigi A, Chen K, Le DS, Reiman EM, Tataranni PA. Brain abnormalities in human obesity: a voxel-based morphometric study. Neuroimage 2006; 31(4):1419-25.

44. Pednekar MS, Hakama M, Hebert JR, Gupta PC. Association of body mass index with all-cause and cause-specific mortality: findings from a prospective cohort study in Mumbai (Bombay), India. International Journal of Epidemiology 2008; 37(3):524-35.

45. Pignatti R, Bertella L, Albani G, Mauro A, Molinari E, Semenza C. Decision-making in obesity: a study using the Gambling Task. Eat Weight Disord 2006; 11(3):126-32.

46. Plewa M, Markiewicz A. Aktywność fizyczna w profilaktyce i leczeniu otyłości. Forum Medycyny Rodzinnej 2007; 1(1):35-44.

47. Przegaliński M, Rutkowska I. Rola fizjoterapii w profilaktyce i leczeniu otyłości oraz zaburzeń ustrojowych z nią związanych. . Rehabilitacja w Praktyce 2008; 4:28-31.

48. Raji CA, Ho AJ, Parikshak NN, Becker JT, Lopez OL, Kuller LH, et al. Brain Structure and Obesity. Human Brain Mapping 2010; 31(3):353-64.

49. Rao R. Bariatric surgery and the central nervous system. Obesity Surgery 2012; 22(6):967-78.

50. Sabia S, Kivimaki M, Shipley MJ, Marmot MG, Singh-Manoux A. Body mass index over the adult life course and cognition in late midlife: the Whitehall II Cohort Study. American Journal of Clinical Nutrition 2009; 89(2):601-7.

51. Sahin I, Alkan A, Keskin L, Cikim A, Karakas HM, Firat AK, et al. Evaluation of in vivo cerebral metabolism on proton magnetic resonance spectroscopy in patients with impaired glucose tolerance and type 2 diabetes mellitus. Diabetes Complications 2008; 22(4):254-60.

52. Scholze J, Alegria E, Ferri C, Langham S, Stevens W, Jeffries D, et al. Epidemiological and economic burden of metabolic syndrome and its consequences in patients with hypertension in Germany, Spain and Italy; a prevalence-based model. Bmc Public Health 2010; 10.

53. Sedek R, Koon PB, Noor IM. Body mass index and body composition among Royal Malaysian Navy (RMN) Personel. The Journal of Defence and Security 2010; 1(1):1-18.

54. Speer S, Speer A. Ambulatoryjne leczenie otyłości u osób dorosłych. Medycyna po Dyplomie 1998; 7:147-57.

55. Staniek M, Niesporek J. Aktywność fizyczna jako podstawowy element kompleksowego leczenia otyłości. Zeszyty MetodycznoNaukowe AWF w Katowicach 2010; 26:113-28.

56. Stingl KT KS, Ketterer C, Heni M, Häring HU, Fritsche A, Preissl H. Neuronal correlates of reduced memory performance in overweight subjects. Neuroimage 2012; 60(1):362-9.

57. Tregellas JR WK, Rojas DC, Tanabe J, Martin J, Kronberg E, Cordes D, Cornier MA. Altered Default Network Activity in Obesity. Obesity 2011; 19(12):2316-21.

58. Uranga RM, Bruce-Keller AJ, Morrison CD, Fernandez-Kim SO, Ebenezer PJ, Zhang L, et al. Intersection between metabolic dysfunction, high fat diet consumption, and brain aging. Journal of Neurochemistry 2010; 114(2):344-61.

59. Valdes AM, Andrew T, Gardner JP, Kimura M, Oelsner E, Cherkas LF, et al. Obesity, cigarette smoking, and telomere length in women. Lancet 2005; 366(9486):662-4.

60. Volkow ND, Wang GJ, Fowler JS, Telang F. Overlapping neuronal circuits in addiction and obesity: evidence of systems pathology. Philosophical Transactions of the Royal Society B-Biological Sciences 2008; 363(1507):3191-200.

61. Volkow ND, Wang GJ, Maynard L, Jayne M, Fowler JS, Zhu W, et al. Brain dopamine is associated with eating behaviors in humans. International Journal of Eating Disorders 2003; 33(2):136-42.

62. Volkow ND, Wang GJ, Telang F, Fowler JS, Goldstein RZ, Alia-Klein N, et al. Inverse Association Between BMI and Prefrontal Metabolic Activity in Healthy Adults. Obesity 2009; 17(1):60-5.

63. Volkow ND, Wang GJ, Telang F, Fowler JS, Thanos PK, Logan J, et al. Low dopamine striatal D2 receptors are associated with prefrontal metabolism in obese subjects: Possible contributing factors. Neuroimage 2008; 42(4):1537-43. 
64. Volkow ND, Wise RA. How can drug addiction help us understand obesity? Nat Neurosci 2005; 8(5):555-60.

65. Waldstein SR, Katzel LI. Interactive relations of central versus total obesity and blood pressure to cognitive function. Int J Obes (Lond) 2006; 30(1):201-7.

66. Wang GJ, Volkow ND, Thanos PK, Fowler JS. Imaging of Brain Dopamine Pathways Implications for Understanding Obesity. Journal of Addiction Medicine 2009; 3(1):8-18.

67. Wang YF, Beydoun MA, Liang L, Caballero B, Kumanyika SK. Will all Americans become overweight or obese? Estimating the progression and cost of the US obesity epidemic. Obesity 2008; 16(10):2323-30.

68. Ward MA, Carlsson CM, Trivedi MA, Sager MA, Johnson SC. The effect of body mass index on global brain volume in middleaged adults: a cross sectional study. BMC Neurol 2005; 5:23.

69. White CL, Pistell PJ, Purpera MN, Gupta S, Fernandez-Kim SO, Hise TL, et al. Effects of high fat diet on Morris maze performance, oxidative stress, and inflammation in rats: Contributions of maternal diet. Neurobiology of Disease 2009; 35(1):3-13.

70. Whitmer RA, Gunderson EP, Quesenberry CP, Jr., Zhou J, Yaffe K. Body mass index in midlife and risk of Alzheimer disease and vascular dementia. Curr Alzheimer Res 2007; 4(2):103-9.

71. Whitmer RA, Gustafson DR, Barrett-Connor E, Haan MN, Gunderson EP, Yaffe K. Central obesity and increased risk of dementia more than three decades later. Neurology 2008; 71(14):1057-64.

72. Willeumier KC TD, Amen DG. Elevated BMI is associated with decreased blood flow in the prefrontal cortex using SPECT imaging in healthy adults. Obesity 2011; 19(5):1095-7.

73. Yaffe K. Metabolic syndrome and cognitive decline. Curr Alzheimer Res 2007; 4(2):123-6.

74. Zanuso S, Jimenez A, Pugliese G, Corigliano G, Balducci S. Exercise for the management of type 2 diabetes: a review of the evidence. Acta Diabetologica 2010; 47(1):15-22.

75. Zatońska K, llow R, Regulska-llow B, Różańska D, Szuba A, Wołyniec M, Einhorn J, Vatten L, Asvold BO, Mańczuk M, Zatoński WA. Prevalence of diabetes mellitus and IFG in the prospective cohort 'PONS' study - baseline assessment. annals of agricultural and environmental medicine 2011; 18(2):265-9.

76. Zdrojewski T, Bandosz P, Szpakowski P, Konarski R, Manikowski A, Wołkiewicz E, et al. Rozpowszechnienie głównych czynników ryzyka chorób układu sercowo-naczyniowego w Polsce. Wyniki badania NATPOL PLUS. Kardiologia Polska 2004; 64(suplement IV):IV1-IV26.

77. Zdrojewski T, Szpakowski P, Bandosz P, Pajak A, Wiecek A, Krupa-Wojciechowska B, et al. Arterial hypertension in Poland in 2002. Journal of Human Hypertension 2004; 18(8):557-62.

Cite this article as: Gaździńska A, Wójcik R, Janewicz M, Binder M, Wyleżoł M, Gazdzinski SP. Excess Body Weight as a Risk Factor to Well-being and Performance of Flight Personnel: Potential Strategies of Prevention. Pol J Aviat Med Psychol 2014; 20(4): 27-36. DOI: $10.13174 /$ pjamp.20.04.2014.4 